\title{
A Promising Connection: Increasing Civic Life Learning through Simulated Civics Education Action
}

\author{
Eleni Makri \\ Organizational Psychologist, Academic Researcher, Athens, Greece
}

In loving memory of my parents, doctor Georgios Makris and teacher Georgia Tsiotou-Makri

\begin{abstract}
Civics knowledge, agency and capacity are considered essential across all ages to help or improve the positive experience of and effect on existing and future civic lifelong learning through different curricula and related actions in social and community field. The present research investigates Greek and Cypriot college students' civic knowledge, attitudes and skills outcomes when they took part in the 3-day experiential learning sessions conducted at the Hellenic Parliament during 2015. The sessions were run as part of the relative Youth Parliament experiential learning programme that simulates the activities of the formal Hellenic Parliament plenary session. The action includes the yearly voluntary participation of 300 mature students aged up to 20 years old from Greece, Cyprus and other European and non-European countries in interactive educational tasks aimed to relate and advance their civic, community and political engagement with universal civics values and culture. 167 college students offered their responses in the case study implementing pre-and-post assessments. Empirical evidence designates positive and direct significant associations between leadership skills, civic responsibility, interpersonal and problemsolving skills, civic action, political awareness and diversity attitudes as well as differences in the aforementioned civic attitudes and skills outcomes based on gender and country of residence (Greece and Cyprus), after Youth Parliament's action. Theoretical and practical implications and streams of further research are discussed in view of civics life context cross-culturally.
\end{abstract}

\section{Introduction}

"Civic learning, which we define as students' progress toward becoming engaged citizens, [who are] proud of their rights, thoughtful about their responsibilities, and informed about their choices" [1 p. 317]

Civic life education is considered to be a multidisciplinary field that aspires to engage young and older individuals in keeping up to speed with their immediate and broader social surroundings (e.g. family, school, neighborhood, region, government, country), exploring discrimination and injustice and improving the well-being of their civic, social and political communities [2 p. 65]. The scholarly debate about how we could define the informed, engaged and dutiful citizen seems to be rather prevailing and open in our society cross-nationally over the decades, both for youth and adults alike. Given a) the current emerging technological, economic, social, political and environmental forces apparent across countries that celebrate a globalized society rapidly accumulating issues of "diversity and cultural pluralism" [3 p. 10], b) the reported disengagement from civic and political interest and participation that young people tend to exhibit cross-nationally [4] and c) the contradictory findings as to the nature and extent of civic learning-related attitudes and skills for college students, in particular, which seem to rely extensively on community action and service programmes disregarding interactive forms of civics education programmes [1], as briefly described below, further exploration of age-associated civic and community engagement paradigms is deemed necessary [5]. In this context, therefore, the research study presented in the current paper pursues to extend the initial evidence of a case study performed at the Hellenic Parliament as part of a cross-cultural simulated civics education action, designated to investigate the participants' (i.e. college students) present and future civic knowledge, attitudes and skills after they joined the corresponding programme during 2015. In accordance with the aforementioned rationale, therefore, the research questions that 
adhere to the scope of the current study are the following:

- Are there any differences in the perceptions of civic attitudes and skills assessed after-Youth Parliament programme based on gender and country of residence?

- Do the civic attitudes and skills facets postYouth Parliament sessions positively affect civic action, political awareness and civic responsibility?

The remainder of this paper is organized as follows. Section 2 illustrates a summary review regarding civic and community engagement knowledge, behavioural intentions and skills research findings in college education domain, crossnationally. Section 3 reports on the research methodology involving the study design, a brief outline of the assessed simulated civics education action and the results' analysis. Section 4 elaborates on their theoretical and practical implications relevant to cross-national civic and community engagement and finishes this paper by upcoming streams of further research on networked dutiful citizenship cross-generationally.

\section{Literature review}

"Students resisted the required nature of their community service; ...had the schools been more actively involved in structuring the requirement and assuring meaningful service, it is reasonable to speculate that the outcomes for students would have looked quite different. None of them resisted service and giving back to the community; indeed, many of them were engaged in this kind of service outside of the requirement"'[6 p. 15]

Cross-disciplinary-and-cultural research on civic and community engagement involving official and unofficial civics education curricula and programmes targeted at younger and adult students, is globally intertwined with assessments that emphasize mature learners' civic and community-related knowledge, attitudes and competencies employed to evaluate their civic and community orientation associated with joint activity in scholarly and societal situations [7]. This focus is additionally strengthened by the prevailing information and communication technology, political, economic, environmental and social powerful change agents across the globe. Those forces have universally allocated young generation (i.e. millennials entering the workforce) with distinguishing encouraging and (or) diverse individual and civic learning attitudes and skills (e.g. culturally and technology literate, collective actionoriented, overly work tasks-focused, wildly selfassured, high flyers, excessively insistent, etc.) [8 p.
228-232], [9 p. 49]. In that respect, millennial youths tend to shape a rather aware but divergent in individual and civics-associated understanding and abilities generation, into which their further exploration of civic learning attitudes and skills within academic curricula and extracurricular events is reckoned as necessary to be incorporated. In turn, this would principally improve research in civic and community involvement within higher education, in specific, which is considered to illustrate contradictory evidence regarding the breadth and depth of civic life-associated properties, claimed to rest upon an excessive degree on service-andcommunity-related activities and misstate other widespread civic-generation and community capacity and behaviour experiences [5], as described, next.

Kisker, Weintraub and Newell [1] illustrate their survey on civic knowledge, attitudes and skills research involving 4.788 college students aged 20-24 in the United States, as follows: students enrolled in community colleges being oriented towards civic and community engagement, indicated advanced levels of intention to advocate the views of themselves and others, lend support to social and political changes, take on leadership roles in their community and (or) workforce, help others in need, understand people from different cultural background and voice responsible attitudes on civic, community and political topics (i.e. civic agency and civic capacity factors). Diverse ethnic and racial tracks were also significantly associated with civic knowledge, attitudes and skills, as outlined next: students originated from non-White background showed improved levels of certain civic attitudes and skills (i.e. civic agency, civic capacity as reported above including civic knowledge based on comprehension of local and cross-national community events) than their counterparts stemming from White race or ethnicity track. However, the same students did indicate reduced levels of civic behaviour (i.e. voice opinions through social media, volunteering, service learning, talk about civic, social, political and community issues, etc.) in relation to their peers from White origin. Female students demonstrated greater levels of civic capacity factor, but decreased ones for civic agency, behaviour and knowledgerelated factors.

Speaking English was positively related to civic behaviour factor, but oppositely associated with civic agency and knowledge aspects. This finding was attributed to the higher level of civic comprehension claimed to be available for native English students entering college in comparison to their peers originating from immigrant track. Age was favourably associated with civic agency and behaviour concepts, while full-time enrollment contributed to advanced levels of civic capacity and knowledge aspects, but adversely related to civic behaviour outcomes (assigned to less time available 
for full-time registered students to be actively involved in civic and community-related activities). Family (i.e. parents') educational and economic background indicated to be negatively connected to civic capacity and knowledge, with the latter being further unfavourably associated with civic behaviour. These findings exhibit the significance of family background in civic attitudes and skills outcomes during college registration. Colleges with greater proportion of students over 24 years old indicated decreased levels of civic agency, knowledge and behaviour, overall, while those offering grants for lower income students reported improved levels of civic agency, possibly due to their proactive attitude towards reducing the social and educational effects of economic inconsistency among students. Scholarly focus on civic engagement was positively related to civic capacity, behaviour and knowledge, but unfavourably associated with civic agency experience. Civic engagement in academic career progression was connected with increased levels of civic behaviour, but inversely related to civic agency and capacity outcomes. Lastly, political engagement was indicated to be favourably associated with civic agency, capacity, behaviour and knowledge facets.

Cheng [10] describes her study involving 98 mature students in Taiwan who participated in a service learning action during the period of the case study. 78 females $(80 \%)$ and 20 males $(20 \%)$ were divided into teams of their choice, with each team developing a service learning project by spending approximately 18 hours to execute it during semester. Upon its' completion, each participant filled out a questionnaire. The students gained practical hands-on experience through their service learning projects above moderate level, improved their professional skills and were able to apply their new knowledge and skills to the real world. $84 \%$ of the students agreed or strongly agreed that the service helped them apply knowledge to the real world. About $70 \%$ of the participants reported that the project had helped them to enhance professional skills. A few students disagreed with the statements about the positive effects of gaining practical experience $(22 \%$ neutral and $2 \%$ disagree, respectively). Overall, the students were able to communicate with others, but they still needed to develop teamwork skills. $80 \%$ of the students reported that the onsite experience made them better understand the importance of effective listening and most of them were able to solve multi-dimensional problems comfortably. Approximately $55 \%$ of the students indicated that the project helped them to develop their problem-solving skills and learn how to create a contingency plan in case of unforeseen circumstances. $73 \%$ of them reported that they learned to think about problems from different perspectives, suggesting that service learning may assist them to practice critical thinking skills for efficient problem-solving. Further, around $62 \%$ of the students strongly agreed or agreed that the service project performed made them more willing to help other nonprofit organizations. The outcomes of this research are claimed to advocate that service learning is a viable approach to assist students to become more engaged and re-connected with their communities. Evidence also showed a moderately increased level of awareness of community needs, engaging social responsibility and the ability to make a difference in the community. About $87 \%$ of the students agreed that they engaged in social responsibility through participation on the community-based project experience. Service learning aided students to comprehend the relevance of communication concepts and enabled them to test arguments and employ them in the work context. Students reported they acquired many significant experiences not usually exercised in a traditional classroom setting and perceived they had become more confident and outgoing. The students' reflections seem to suggest that they benefited not only through the combination of academic learning and its practical employment to real-life conditions, but also through their growing awareness of a range of issues, such as civic engagement and social responsibility facets. Based on their responses, this kind of project seemed to advance the likelihood of them becoming more proactive and responsible citizens in the future.

Kirlin [11] describes 3 studies involving a) 70 college students registered in a public relations module, b) 108 youth aged 18 enrolled in a youth and government programme and c) 1.069 adult participants enrolled in youth and government programmes at a national level in the United States, as part of their extracurricular instruction activities. All surveys aimed to explore the participants' civic attitudes and skills pertaining to civic and community engagement. As regards the overall comparison of the participants in the first 2 studies, the students who took part in their youth and government programme appeared to indicate greater confidence in civic and community engagement and related self-efficacy concepts than their peers in the other groups. For the last study, participation was considerably higher for young and government alumni than the general population on all measures of civic engagement and for several subgroups tested, including alumni with less income or education and those whose parents had jobs that did not require a college degree. Overall, youth and government alumni participated at higher rates than the national average.

Finkel and Ernst [12] report on their 3 studies involving 261 students trained in the Democracy For All civics education program in South African secondary education institutions, 124 youths having experienced some form of civics education at school 
and 215 students with no prior enrollment in formal civics curricula. All 3 student groups above consisted of diverse ethnic origin within South African culture. In total, exposure to civic education had relatively strong effects on political knowledge and to a lesser extent, approval of political participation, while having no impact on values such as civic duty, tolerance, trust, or the acquisition of participatory skills. Civics training appeared to have a relatively positive influence on political knowledge among students. Civic education exposure had no effect on students' civic duty, tolerance, institutional trust, or civic skills, once other factors such as family political discussion and own level of media exposure and prior political interest were considered. The quality of civics instruction was indicated as a significant factor for favourable change on civic duty, institutional trust and civic skills. The more students engaged in group projects and other interactive classroom activities, the more they exhibited higher levels of tolerance, civic duty, and approval of legal behaviours. I su, civics education training in South Africa, then, seemed to foster interrelatedness among democratic values and a finer distinction between different aspects of democratic citizenship.

Dassonneville, Quintelier, Hooghe, and Claes [13] elaborate on a 2-wave political panel study performed in Belgium, as follows. In 2006 surveying 6.330 16-year-olds students and in 2008 the same respondents at the age of 18 . In total, 4.235 students $(67 \%)$ from the preliminary cohort were re-surveyed either through interviews and (or) mail responses. Male students were more interested in politics than females. Higher socioeconomic status leaded to increased political interest. The level of political interest measured in 2006 appeared to be a strong predictor of political interest in 2008, indicating that political interest may tend to remain stable over time. Students in the French community were found to be more politically efficacious, as were the students with a higher socioeconomic status. An open classroom climate and joint decision-making at school did not appear to be related to students' political efficacy (i.e. comprehension of politics). Classroom instruction was associated with the level of understanding politics (i.e. political efficacy). Political efficacy assessed in 2006 was a strong predictor of students' 2008 efficacy levels. Higher socioeconomic status was also indicated to have a positive impact on political trust. The latter was found to be related to open classroom climate. Political trust (i.e. level of trust in the Belgian, the regional and European parliament, the federal government and political parties) seemed to remain rather stable over time, as its level observed in 2006 was a strong predictor of the corresponding 2008 level. Finally, school council membership was linked to students' active involvement in politics for both cohorts.

Gillman [14] describes her study including 186 students aged 14-24 attending high school, college or other educational entities in terms of their civic and political knowledge, attitudes and skills, as follows. Respondents did not relate democracy with formal democratic institutions, many of them described political institutions as the opposite of democracy, as part of the negative arena of politics rather than the positive aspect of democracy. Ecuadorian students conceptualized democracy in terms of individual virtues and societal ideals. Many participants related democracy to positive individual traits such as responsibility, respect, honesty, loyalty, commitment and moral values or suggesting attributes linked to intimate relationships like love, friendship and understanding. Democratic participation was associated with ethical and charitable qualities (e.g. helping others in need). Democracy was further related to collective ideals and values. Especially within rural areas, students stressed the societal pressures that may prevent them from practicing these freedoms. By and large, students did illustrate democracy not as a system of government, but rather as an issue of social values and exercise.

Eckstein and Noack [15] report on their study of 219 vocational and high school students aged 16-25 (138 of German- and 81 of Turkish-origin, respectively) in Germany involving their active citizenship, classroom climate and value of social studies experienced. The researchers investigated the association between different experiences at school and 4 indicators of youth active citizenship, controlling for various socio-demographic information. Open classroom climate and classroom community were associated with greater active citizenship among Turkish-origin students, while engagement in school decisions was associated with active citizenship among German-origin students. Participants who were older, male, of higher socioeconomic status and more positively oriented towards civic education, were more politically attentive. The impact of open classroom climate on political attentiveness was significant for Turkishorigin but not for German-track students. Respondents who were older, of higher socioeconomic status and more positively oriented towards civic education, were more civically proactive. The effect of opportunities to participate in school decisions on collective efficacy was significant among German- but not among Turkishorigin students. The adverse pattern was indicated for classroom community. The impact of open classroom climate on political trust was significant among Turkish- but not among German-track participants. Classroom climate was more strongly related to active citizenship among Turkish- than among German-origin students. Participation in 
school decisions was associated with political trust and collective efficacy among German- but not among Turkish-origin respondents. The researchers attribute the above findings to the participatory structures in school that may reflect instructed ways of engagement and may, therefore, stronger related to political trust among German-origin students. Thus, engaging in activities at school that involve dealing with school authorities and formal decisionmaking processes may help to build trust in political agency and institutions among non-immigrants. Another possible explanation of them is claimed to rest upon the operationalization of this concept. Their indicator the extent to which students perceived they could influence school decisions and might therefore further reflect individual perceptions of influence and efficacy. Hence, German-origin students might be more likely than their Turkishorigin ones to project their own individual agency onto the agency of the group (i.e., collective efficacy). In addition, the value of social studies was related to 3 out of 4 active citizenship indicators and these associations were not moderated by ethnic track. Overall, the researchers claim that if educational entities wish to advance active citizenship in all of their students, they may need to adapt their efforts to fit the diverse needs of ethnic student groups.

Cohen and Chaffee [16] report on their 2010 study including 981 public urban middle and high school students in the United States performed at the beginning of the school year and before participating in a citizen classroom-related civics curriculum or other social studies and civics courses project. The survey aimed at exploring the students' civic knowledge, attitudes and skills including the likelihood of voting. 59\% of the respondents reported that they would be likely or extremely likely to vote in the future. Very few students answered correctly all questions related to content knowledge (i.e. USA governance) (2\%), current events $(2 \%)$ or local knowledge (i.e. identification of their political representatives) (3\%). Students were least likely to fall into the lowest category of either general or skillspecific self-efficacy, while most of them reported general previous civic experience with volunteering and experience in at least 1 of 8 specific civic skillrelated activities. Civic content knowledge, current events knowledge, general self-efficacy and skillspecific self-efficacy maintained favourable association with the likelihood of future voting after controlling for ethnicity track and (or) placement experience. These findings tend to be consistent with prior ones (e.g. [17]) that indicate civic knowledge and self-efficacy as strong predictors of intended future voting among adolescents.

\section{Research methodology}

This section illustrates the study design adopted, a brief description of the Youth Parliament programme and the empirical evidence analysis obtained, as follows.

\subsection{Study design}

The Youth Parliament case study adopted the preand-post assessment (experimental design) when the 300 mature students from Greece and other European countries of different educational track took part in the relevant 3-day experiential and civics education simulated sessions executed at the Hellenic Parliament in the year 2015. Approximately a week before they participate in the scheduled sessions, the students were asked to fill in an online questionnaire with demographic and background information regarding age, gender, country of residence, nature of educational institution, employment status and registration to vote statements, as well as civic attitudes and skills items that specifically addressed leadership and interpersonal and problem-solving skills, civic action and responsibility, diversity attitudes and political awareness factors. Similarly, about a week after their participation in the sessions followed, they completed the same online postcivics-related action instrument. In total, 167 college students answered both the before-and-after civic attitudes and skills questionnaire that addressed civic knowledge, behavioural intentions and skills concepts through relevant questions adopted for the needs of the present research. These were multiple choice items with answers marked on a 5-point Likert type format based on level of agreement or disagreement with each statement (1=completely disagree to $5=$ completely agree). Each one of the pre-and-post questionnaires involved 6 scales, 5 of which were employed from Civic Attitudes and Skills Questionnaire [18] (i.e. leadership skills, civic action, interpersonal and problem-solving skills, diversity attitudes and political awareness) and 1 from [19] (i.e. civic responsibility). Items that were negatively worded for presentation were reverse coded before analyses were conducted.

\subsection{Youth parliament}

Youth parliament is an experiential learning action (i.e. head-on experience, speculation, ongoing learning and instant feedback) that simulates the operation and tasks performed during the regular plenary Parliament session. 300 mature students up to 20 years old from Greece, Cyprus and other countries within and outside the European Union participate in the action sessions organized each year. The deployed sessions are targeted to assist and improve students' civic and community knowledge, 
attitudes and skills through engaging focus groups discussions and assuming role-tasks fostered by faceto-face meetings, reflection and feedback provided.

\subsection{Data analysis and results}

108 female and 59 male college students $(\mathrm{N}==167)$ offered before-and-after civic attitudes and skills instruments overall, accounting for $64.67 \%$ and $35.33 \%$ of the total sample, respectively. The majority of students derived from Greece and Cyprus (99\%). Furthermore, to investigate potential differences in the experience of leadership and interpersonal and problem-solving skills, civic action and responsibility, diversity attitudes and political awareness, as well as possible positive associations between the aforementioned variables among participants post-Youth Parliament sessions, the following analyses were performed: a) 2 (country of residence: Greece vs Cyprus) x 2 (gender: male vs female) between groups ANOVAs in order to determine the impact of country of residence and gender on students' scores in each of the civic attitudes and skills scales used, as measured by the post-civics-related programme questionnaire, the results of which are reported in Tables 1, 2 and Figure 1 that follow below and b) hierarchical regression analyses for the prediction of civic action, political awareness and civic responsibility variables after students' participation in the Youth Parliament action, the outcomes of which are presented in Tables 3, 4 and 5 that follow next, accordingly.

\section{$2 \times 2$ ANOVAs}

Table 1 presents the relevant descriptive statistics that correspond to students' responses to each one of the civic attitudes and skills variables measured postYouth Parliament assessment by country of residence (i.e. Greece, Cyprus) and gender (male, female), where Table 2 reports the main and interaction effects for country of residence (i.e. Greece, Cyprus) and gender (male, female) for each of the aforementioned civic attitudes and skills variables assessed after students' participation in the Youth Parliament action. Finally, Figure 1 illustrates the nature of the interaction effect indicated in terms of country of residence and gender for civic action scores post-Youth Parliament measurement.
Table 1. Descriptives of students' responses by country of residence and gender

\begin{tabular}{|c|c|c|c|}
\hline \multirow{2}{*}{$\begin{array}{l}\text { Civic } \\
\text { Attitudes and } \\
\text { Skills }\end{array}$} & \multirow{2}{*}{$\frac{\mathrm{d}}{\mathrm{M}}$} & \multirow{2}{*}{ Greece } & \multirow{2}{*}{ Cyprus } \\
\hline & & & \\
\hline Diversity & \multicolumn{3}{|c|}{ Male $3.60(3.55) 3.61(3.35) 3.50(3.52)$} \\
\hline \multirow[t]{2}{*}{ Attitudes } & Female & $\mathrm{e} 3.80(3.54) 3.84$ & 3.54 \\
\hline & Total & 3.60 & 3.72 \\
\hline Political & \multicolumn{3}{|c|}{ Male $4.50(4.74) 4.49(4.36) 5.00(4.50)$} \\
\hline \multirow[t]{2}{*}{ Awareness } & Female & $4.21(3.99) 4.25$ & 4.01 \\
\hline & Total & 4.34 & 4.16 \\
\hline Civic & \multicolumn{3}{|c|}{ Male $4.12(4.15) 4.12(3.92) 4.18(4.03)$} \\
\hline \multicolumn{3}{|c|}{ ResponsibilityFemale4.14(3.98)4.19 } & 3.88 \\
\hline \multirow{4}{*}{ Civic Action } & Total & 4.16 & 3.93 \\
\hline & \multicolumn{3}{|c|}{ Male $4.17(4.36) 4.16(4.03) 4.56(4.18)$} \\
\hline & Female & $4.26(4.27) 4.31$ & 3.80 \\
\hline & Total & 4.25 & 3.92 \\
\hline \multirow{3}{*}{$\begin{array}{l}\text { Leadership } \\
\text { Skills }\end{array}$} & \multicolumn{3}{|c|}{ Male $3.63(3.76) 3.62(3.41) 3.90(3.64)$} \\
\hline & Female & $3.59(3.60) 3.61$ & 3.38 \\
\hline & Total & 3.61 & 3.46 \\
\hline \multirow{3}{*}{$\begin{array}{l}\text { Interpersonal } \\
\text { and Problem- } \\
\text { Solving Skills }\end{array}$} & Male & \multicolumn{2}{|c|}{$4.48(4.47) 4.48(4.64) 4.45(4.39)$} \\
\hline & Female & $4.51(4.68) 4.51$ & 4.33 \\
\hline & Total & 4.50 & 4.35 \\
\hline
\end{tabular}

Notes: Male $\mathrm{N}=56$; Female $\mathrm{N}=108$; Total $\mathrm{N}=164$; Residence in Greece N=146;

Residence in Cyprus $=15$ Total $\mathrm{N}=161$

Table 2. Main effects and interaction effect of country of residence and gender on students' responses

\begin{tabular}{|c|c|c|c|c|}
\hline \multirow[t]{2}{*}{$\begin{array}{l}\text { Civic } \\
\text { Attitudes } \\
\text { Skills }\end{array}$} & \multicolumn{4}{|c|}{$\begin{array}{l}\text { Main effectMain effectInteraction } \\
\text { dfor countryfor gender effect } \\
\text { of residence }\end{array}$} \\
\hline & \multicolumn{2}{|c|}{$\overline{F(6,155) p} \quad \overline{F(2,155) p}$} & \multicolumn{2}{|c|}{$F(1,155) p$} \\
\hline Diversity & 1.292 & .2631 .005 & .368 .085 & .771 \\
\hline $\begin{array}{l}\text { Political } \\
\text { Awareness }\end{array}$ & .678 & .6674 .104 & .0183 .093 & .781 \\
\hline Civic & $F(6,146)$ & $F(2,146)$ & \multicolumn{2}{|c|}{$\mathrm{F}(1,146)$} \\
\hline \multicolumn{5}{|c|}{ Responsibility } \\
\hline \multirow[t]{2}{*}{ Civic Action } & $\begin{array}{l}.599 \\
F(6,154)\end{array}$ & $\begin{array}{r}.7311 .030 \\
F(2,154)\end{array}$ & $\begin{array}{r}.360 .755 \\
F(1,1\end{array}$ & .386 \\
\hline & .781 & .5861 .454 & .2374 .009 & .047 \\
\hline \multirow[t]{2}{*}{$\begin{array}{l}\text { Leadership } \\
\text { Skills }\end{array}$} & $\mathrm{F}(6,152)$ & $\mathrm{F}(2,152)$ & \multicolumn{2}{|c|}{$\mathrm{F}(1,152)$} \\
\hline & .195 & .978 .919 & .401 .933 & .336 \\
\hline \multirow[t]{2}{*}{$\begin{array}{l}\text { Interpersonal } \\
\text { and Problem } \\
\text { Solving Skill }\end{array}$} & $\mathrm{F}(6,154)$ & $\mathrm{F}(2,154)$ & $\mathrm{F}(1,1$ & \\
\hline & .958 & .455 .518 & .597 .221 & .639 \\
\hline
\end{tabular}




\section{Diversity Attitudes}

As can be seen in Tables 1 and 2 above, there was a non-significant main effect of the country of residence on students' diversity attitudes post-Youth Parliament session, F $(6,155)=1.292, \mathrm{p}=.263$, partial $\eta^{2}=.048$, which means that participants from Greece and Cyprus scored similarly in their perceptions of diversity attitudes post-Youth Parliament action $(\mathrm{M}=3.35$ and $\mathrm{M}=3.52$, accordingly)(estimated marginal means). There was a non-significant main effect of gender on students' diversity attitudes scores after Youth Parliament participation, $\mathrm{F}(2,155)=1.005, \quad \mathrm{p}=.368$, partial $\eta^{2}=.013$, which means that male and female students did indicate similar scores in their perceptions of diversity attitudes post-Youth Parliament programme $(\mathrm{M}=3.55$ and $\mathrm{M}=3.54$, respectively)(estimated marginal means). There was a non-significant interaction effect between the country of residence and gender on students' post-Youth Parliament diversity scores, $\mathrm{F}(1,155)=.085, \mathrm{p}=.771$, partial $\eta^{2}=.001$. This indicates that Youth Parliament's college students reflecting males and females from Greece and Cyprus were not affected differently in their perceptions of diversity. Specifically, the perceptions of diversity attitudes indicated by students residing in Greece ( $M=3.75)$ (means) were similar with those reported by the ones residing in Cyprus ( $\mathrm{M}=3.53)$ (means) $\left(\mathrm{x}^{2}(16)=34.85, \mathrm{p}=.113\right.$ $\mathrm{ns})$. Likewise, diversity attitudes perceptions were similar in male $(\mathrm{M}=3.60)$ (means) and female $(\mathrm{M}=3.80)$ students (means) $\left(\mathrm{x}^{2}(32)=32.165, \mathrm{p}=.459\right.$ $\mathrm{ns})$.

\section{Political Awareness}

There was a significant main effect of gender on student's political awareness scores after Youth Parliament session, $\mathrm{F}(2,155)=4.104, \mathrm{p}<.05$, partial $\eta^{2}=.050$, which means that male students scored significantly higher in political awareness perceptions $(\mathrm{M}=4.74)$ (estimated marginal means) than their female peers $(M=3.99)$ (estimated marginal means) post-Youth Parliament participation. There was a non-significant main effect of the country of residence on students' political awareness after Youth-Parliament, $F(6,155)=.678, p=.667$, partial $\eta^{2}=.026$, which means that students who resided in Greece and Cyprus scored similarly in political awareness $(\mathrm{M}=4.36$ and $\mathrm{M}=4.50$, respectively)(estimated marginal means). There was a non significant interaction effect between the country of residence and gender on students' perceptions of political awareness after Youth Parliament session, $\mathrm{F}(1,155)=3.093$, $\mathrm{p}=.781$, partial $\eta^{2}=.020$, which indicates that students from Greece and Cyprus and male and female genders were not influenced differently in their perceptions of political awareness by participating in the Youth Parliament civics programme. Specifically, the perceptions of political awareness indicated by students residing in Greece ( $\mathrm{M}=4.34)$ (means) were similar with those reported by the ones residing in Cyprus $(\mathrm{M}=4.16)$ (means) $\left(\mathrm{x}^{2}(13)=11.323, \mathrm{p}=.540\right.$ ns). Likewise, political awareness perceptions were similar in male $(\mathrm{M}=4.50)$ (means) and female $(\mathrm{M}=4.21)$ students (means) $\left(\mathrm{x}^{2}(26)=30.028, \mathrm{p}=.266\right.$ $\mathrm{ns})$.

\section{Civic Responsibility}

There was a non-significant main effect of the country of residence on students' civic responsibility attitudes post-Youth Parliament session, $\mathrm{F}(6,146)=$ $.599, \mathrm{p}=.731$, partial $\eta^{2}=.024$, which means that participants from Greece and Cyprus scored similarly in their perceptions of civic responsibility post-Youth Parliament action ( $M=3.92$ and $M=4.03$, accordingly) (estimated marginal means). There was a non-significant main effect of gender on students' civic responsibility attitudes scores after Youth Parliament participation, $\mathrm{F}(2,146)=1.030, \mathrm{p}=.360$, partial $\eta^{2}=.014$, which means that male and female students did indicate similar scores in their perceptions of civic responsibility post-Youth Parliament programme $(M=4.15$ and $M=3.98$, respectively) (estimated marginal means). There was a non-significant interaction effect between the country of residence and gender on students' postYouth Parliament civic responsibility scores, $\mathrm{F}(1,146)=.755, \quad \mathrm{p}=.386$, partial $\eta^{2}=.005$. This indicates that Youth Parliament's college students reflecting males and females from Greece and Cyprus were not affected differently in the perception of civic responsibility. In specific, the perceptions of civic responsibility attitudes indicated by students residing in Greece ( $M=4.16)$ (means) were similar with those reported by the ones residing in Cyprus $(\mathrm{M}=3.93)$ (means) $\left(\mathrm{x}^{2}(24)=24.501\right.$, $\mathrm{p}=.430 \mathrm{~ns})$. Likewise, civic responsibility perceptions were similar in male $(\mathrm{M}=4.12)$ (means) and female $(\mathrm{M}=4.14)$ students (means) $\left(\mathrm{x}^{2} \quad(48)\right.$ $=54.523, \mathrm{p}=.240 \mathrm{~ns})$.

\section{Civic Action}

There was a non-significant main effect of the country of residence on students' civic action attitudes post-Youth Parliament session, $\mathrm{F}(6,154)=$ $.781, \mathrm{p}=.586$, partial $\eta^{2}=.030$, which means that participants from Greece and Cyprus scored similarly in their perceptions of civic action postYouth Parliament assessment ( $\mathrm{M}=4.03$ and $\mathrm{M}=4.18$, accordingly) (estimated marginal means). There was a non-significant main effect of gender on students' civic action scores after Youth Parliament participation, $\mathrm{F}(2,154)=1.454, \quad \mathrm{p}=.237$, partial 
$\eta^{2}=.019$, which means that male and female students did indicate similar scores in their perceptions of civic action post-Youth Parliament experience $(\mathrm{M}=4.36$ and $\mathrm{M}=4.27$, respectively) (estimated marginal means). There was a significant interaction effect between the country of residence and gender on students' perceptions of civic action after Youth Parliament session, $\mathrm{F}(1,154)=4.009, \mathrm{p}<.05$, partial $\eta^{2}=.025$. This indicates that students from Greece and Cyprus and male and female genders were influenced differently in their perceptions of civic action post-Youth Parliament's programme. In particular, the perceptions of civic action of students that reside in Greece ( $M=4.25)$ (means) were significantly higher than those indicated by the students that live in Cyprus $(M=3.92)$ (means) $\left(x^{2}\right.$ (19) $=44.155, \quad \mathrm{p}<.01)$ after Youth Parliament assessment. Perceptions of civic action indicated by females $(M=4.26)$ (means) were significantly higher than those exhibited by males $(\mathrm{M}=4.17)$ (means) post-Youth Parliament experience $\left(\mathrm{x}^{2}(38)=54.999\right.$, $\mathrm{p}<.05)$. Figure 1 below illustrates the nature of the interaction effect, indicating that Cyprus as country of residence significantly affects civic action perceptions in males (females appear unaffected).

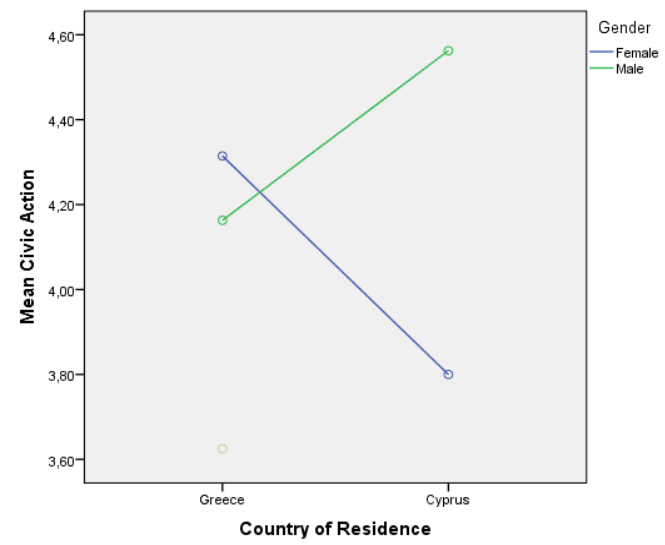

Figure 1. Graph of the interaction of country of residence and gender in civic action

\section{Leadership Skills}

There was a non-significant main effect of the country of residence on students' leadership skills after Youth Parliament's activity, F $(6,152)=.195$, p $=.978$, partial $\eta^{2}=.008$, which means that participants from Greece and Cyprus scored similarly in their perceptions of leadership skills post-Youth Parliament action ( $M=3.41$ and $M=3.64$, accordingly) (estimated marginal means). There was a non-significant main effect of gender on students' leadership skills scores post-Youth Parliament session, $\mathrm{F}(2,152)=.919, \mathrm{p}=.401$, partial $\eta^{2}=.012$, which means that male and female students did indicate similar scores in their perceptions of leadership skills post-Youth Parliament programme $(\mathrm{M}=3.76$ and $\mathrm{M}=3.60$, respectively) (estimated marginal means). There was a non-significant interaction effect between the country of residence and gender on Youth Parliament's students leadership skills scores, $\mathrm{F}(1,152)=.933, \mathrm{p}=.336$, partial $\eta^{2}=.006$. This indicates that male and female students from Greece and Cyprus were not affected differently in the perception of leadership skills after Youth Parliament programme. Specifically, the perceptions of leadership skills indicated by students residing in Greece ( $M=3.61)$ (means) were similar with those reported by the ones residing in Cyprus $(\mathrm{M}=3.46)$ (means) $\left(\mathrm{x}^{2}(16)=26.124, \mathrm{p}=.195 \mathrm{~ns}\right)$. Likewise, leadership skills scores were similar in male $(\mathrm{M}=3.63)$ (means) and female $(\mathrm{M}=3.59)$ students (means) $\left(\mathrm{x}^{2}(32)=21.372, \mathrm{p}=.788 \mathrm{~ns}\right)$.

\section{Interpersonal and Problem-Solving Skills}

There was a non-significant main effect of the country of residence on students' interpersonal and problem-solving skills after Youth Parliament programme, $\mathrm{F}(6,154)=.958, \mathrm{p}=.455$, partial $\eta^{2}=.036$, which means that participants from Greece and Cyprus scored similarly in their perceptions of interpersonal and problem-solving skills post-Youth Parliament action $(\mathrm{M}=4.64$ and $\mathrm{M}=4.39$, respectively) (estimated marginal means). There was a non-significant main effect of gender on students' interpersonal and problem-solving skills scores postYouth Parliament participation, $\mathrm{F}(2,154)=.518$, $\mathrm{p}=.597$, partial $\eta^{2}=.007$, which means that male and female students did indicate similar scores in their perceptions of interpersonal and problem-solving skills post-Youth Parliament programme ( $M=4.47$ and $\mathrm{M}=4.68$, respectively) (estimated marginal means). There was a non-significant interaction effect between the country of residence and gender on students' post-Youth Parliament interpersonal and problem-solving skills scores, $\mathrm{F}(1,154)=.221$, $\mathrm{p}=.639$, partial $\eta^{2}=.001$. This indicates that male and female students that resided in Greece and Cyprus were not affected differently in the perception of interpersonal and problem-solving skills post-Youth Parliament's action. In particular, the perceptions of interpersonal and problem-solving skills indicated by students residing in Greece ( $M=4.50)$ (means) were similar with those reported by the ones residing in Cyprus $(\mathrm{M}=4.35)$ (means) $\left(\mathrm{x}^{2}(21)=31.046, \mathrm{p}=.128\right.$ $\mathrm{ns})$. In the same way, interpersonal and problemsolving skills scores were similar in male $(\mathrm{M}=4.48)$ (means) and female $(\mathrm{M}=4.51)$ students (means) $\left(\mathrm{x}^{2}\right.$ $(42)=32.219, \mathrm{p}=.299 \mathrm{~ns})$. 


\section{Hierarchical regressions}

Hierarchical regression analyses were executed to test for the prediction of civic action, political awareness and civic responsibility after Youth Parliament session. Before proceeding with hierarchical regressions, we assured that all prerequisite conditions related with this analysis (e.g. lack of multicollinearity, deviations from normality, and influential cases) were met. The results from these analyses are presented in Tables 3, 4 and 5 below. In all analyses corresponding each time to the prediction after, respectively, at the first step we entered the control variable (i.e. gender) and then the rest of the independent variables again after (interpersonal and problem-solving skills, leadership skills and diversity attitudes), accordingly. The results presented in Tables 3, 4 and 5 indicate the outcomes of the final relationships occurred between the prospective variables.

Significant relationships were indicated between interpersonal and problem-solving skills after, civic responsibility after and civic action after $(\beta=.26$, $\mathrm{p}<.001$ and $\beta=.55, \mathrm{p}<.001$, respectively), signifying civic responsibility after as the best predictor as above, with the final model explaining an additional 2.1 percent $(\mathrm{F}(6,142)=30.12, \mathrm{p}<.001)$ of the variance in civic action after scores (Table 3 below).

Table 3. Hierarchical regression analyses predicting Civic Action after Youth Parliament session

\begin{tabular}{|c|c|c|c|}
\hline & \multicolumn{3}{|c|}{ Civic Action after } \\
\hline & $\beta$ & $R^{2}$ & $\Delta R^{2}$ \\
\hline \multicolumn{4}{|c|}{$\begin{array}{l}\text { Step 1: Control variables } \\
\text { Gender }\end{array}$} \\
\hline Step 2: Main effects & & $0.55^{* *}$ & $0.21 * *$ \\
\hline \multicolumn{4}{|c|}{$\begin{array}{l}\text { Interpersonal and problem- } 0.26 * * * \\
\text { solving skills after }\end{array}$} \\
\hline Leadership skills after & \multicolumn{3}{|l|}{0.06} \\
\hline Civic responsibility after & \multicolumn{3}{|l|}{$0.55 * * *$} \\
\hline \multicolumn{4}{|c|}{ Notes: $* * * \mathrm{p}<.001$ (one-tailed), $\mathrm{N}=149$} \\
\hline \multicolumn{4}{|c|}{$\begin{array}{l}\text { Significant associations were indicated between } \\
\text { interpersonal and problem-solving skills after, } \\
\text { leadership skills after, civic responsibility after, } \\
\text { diversity attitudes after and political awareness after } \\
(\beta=.40, \mathrm{p}<.001, \beta=.22, \mathrm{p}<.01, \beta=.23, \mathrm{p}<.01 \text { and } \beta=- \\
12, \mathrm{p}<.10, \text { accordingly), showing interpersonal and } \\
\text { problem-solving skills as the best predictor as above, } \\
\text { with the final model explaining an additional } 1 \\
\text { percent }(\mathrm{F}(6,142)=21.91, \mathrm{p}<.001) \text { of the variance in } \\
\text { political awareness after scores (Table } 4 \text { below). }\end{array}$} \\
\hline
\end{tabular}

Table 4. Hierarchical regression analyses predicting Political Awareness after Youth Parliament session

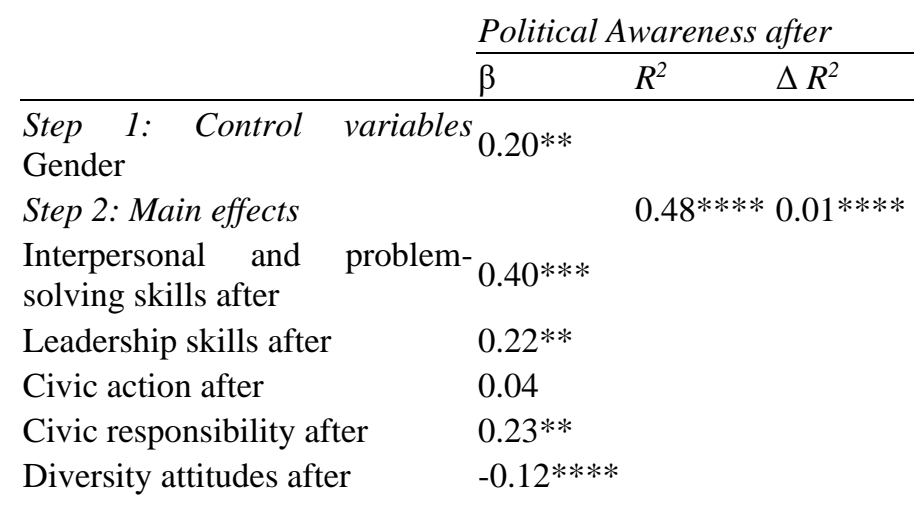

Notes: ** $\mathrm{p}<.01$ (one-tailed); ***p $<.001$ (onetailed); $* * * * p<.10$ (one-tailed); $\mathrm{N}=149$

Finally, significant relationships were indicated between civic action after, political awareness after, diversity attitudes after and civic responsibility after $(\beta=.52, \quad \mathrm{p}<.001, \quad \beta=.20 \quad \mathrm{p}<.10$ and $\beta=.12, \mathrm{p}<.05$, respectively), demonstrating civic action as the best predictor as above, with the final model explaining an additional 1 percent $(\mathrm{F}(6,142)=30.12, \mathrm{p}<.001)$ of the variance in civic responsibility after scores (Table 5 below).

Table 5. Hierarchical regression analyses predicting Civic Responsibility after Youth Parliament session

Civic Responsibility

\begin{tabular}{cc}
\multicolumn{3}{c}{ after } \\
\hline$\beta$ & $R^{2} \quad \Delta R^{2}$
\end{tabular}

Step 1: Control variables Gender $\quad-0.03$

Step 2: Main effects $0.56^{*} 0.01^{*}$

Interpersonal and problem-solving skills after

Leadership skills after $\quad 0.12$

Civic action after $0.52 * * *$

Political awareness after $\quad 0.20 * * * *$

Diversity attitudes after $0.12 *$

Notes: *p<.05 (one-tailed); ***p $<.001 \quad$ (onetailed); $* * * * \mathrm{p}<.10$ (one-tailed); $\mathrm{N}=149$

\section{Discussion and Conclusion}

The findings indicated in the present research seem to lend support to the argument that the assessed experiential civic learning programme appeared to connect college students cross-culturally (i.e. in Greece and Cyprus) with knowledge, behavioural intentions and competencies beneficial in proactively proceed with civic life issues and activities, corroborating and extending prior results that relate different civics curricula and 
extracurricular programmes across countries and mature populations [11] with current and future civic and community engagement and political participation within Greece and Cyprus. The difference indicated in the intention to become involved in the future in community services including volunteering and environment actions (i.e. civic action) and thus, triggering a favourable distinction for students residing in Greece in relation to their peers in Cyprus, is in line with previous ones that relate differences in civic and community knowledge, attitudes and skills experienced by mature students who assume active community membership to cultural interplay, origin and region track [1], [15]. Awareness of present local, national and global community and political issues (i.e. political awareness) appeared to be along similar levels for male and female students residing in Greece and Cyprus. This contradicts prior ones in other countries that reflect different perceptions of civic-and community-associated agency, capacity, behaviour and knowledge exercised among male and female students registered in civics curricula and (or) service action programmes alike [13], [18].

Moreover, the students of both countries who were able to listen to and take the role of others, use their communication skills, cooperate successfully, employ their logical reasoning and problem-solving capacity (i.e. interpersonal and problem-solving skills), positive and proactive in assisting members of their region and participating in community service organizations (i.e. civic responsibility), practiced more their intention to do volunteer work, help people in need, be positively oriented towards making a favourable difference and involved in environment engagement (i.e. civic action) after their participation in the assessed simulated civis learning programme. This favourable outcome expands similar positive findings obtained for college students in service-learning and civics curricula in the United States [20] to simulated civics education programmes ones for similar populations in different countries (cross-culturally).

In addition, Greek and Cypriot students' knowledge and comprehension of issues and events linked to the nation, the world, the neighborhood and the local community including favourable attitude towards active involvement in political activities (i.e. political awareness) post-simulated civics education programme, was associated on one hand, with gender, effective ability to think and relate to the views of others, work cooperatively, be socially active and friendly, use logic, critical thinking and problem-solving skills (i.e. interpersonal and problem-solving skills). On the other, with competence to exercise leadership beneficially (i.e. leadership skills), proactive engagement with community service organizations to help disadvantaged or deprived populations (i.e. civic responsibility) and positive orientation towards relating to culturally-different individuals (i.e. diversity attitudes). These additional encouraging findings tend to be in line with and extend prior ones which relate youth with favourable civics education programmes-associated attitudes and skills in South Africa [12] to similar ones in homogeneous student cohorts (i.e. mature learners) but in different countries like Greece and Cyprus. Analogous promising results were those strongly illustrated in the prediction of favourable attitude towards offering assistance to people in need through community services and resources per se (i.e. civic responsibility), reflecting interest and involvement in the future in certain community service actions (i.e. civic action), by mature students in Greece and Cyprus who are aware of current local, national and international issues related to political process and community schemes (i.e. political awareness) and experience enjoyment when efficiently relate to people from various racial, ethnic and (or) cultural origin (i.e. diversity attitudes). Such evidence lends support to previous ones reflecting positive youth civics life experience for service learning and civics curricula assessments in Taiwan [10], but in contrast with others that indicate mature students' and instructors' disengagement indicators from civic learning knowledge and practice due to limited open school civics climate perceptions in Canada [21].

As illustrated above, the acquired findings indicate the positive civic life self-motivated experience for college students registered in the explored simulated civics education programme and demonstrate the heterogeneity of civics-associated practice by gender and country of residence factors. In that sense, therefore, they expand previously obtained culturespecific favourable civic knowledge, attitudes and skills outcomes for service-learning curricula of mature students to seemingly positive ones for simulated civics programmes for similar populations including individual variables in different countries. In that sense, therefore, they contribute to the development of current civics education stream that posits the need to a) investigate a wide-ranging scope of civic and community engagement activities involving not only formal civics curricula but diverse civics learning-related programmes (e.g. simulated, experiential learning and game-based civics actions, youth mentoring, environmental campaign activities, youth and government organizations, etc.) [22] and b) evaluate civic and community engagement attitudes and skills patterns across generations (i.e. youth/millennials) and countries (i.e. European, North American, Asian, etc.) [23]. Along this vein, it would be helpful to expand, for example, the present study design and outcomes by comparing the assessed simulated civics learning programme with different ones performed in other nations and diverse groups. Including additional exploration of the ways 
socioeconomic status (e.g. family civic perceptions and economic and educational background), ethnic or racial origin (e.g. immigrants), age (e.g. adults over 50) and social media platforms (e.g. Facebook, Twitter, blogging, etc.) might prevent or help the development of knowledgeable and conscientious young and older citizens in our era.

\section{Acknowledgements}

The author thanks the Youth Parliament participating students that made this study possible.

\section{References}

[1] C.B. Kisker, D.S. Weintraub, and M.A. Newell, "The Community Colleges' Role in Developing Students' Civic Outcomes: Results of a National Pilot", Community College Review, 44, 4, 2016, pp. 315-336

[2] C.B. Kisker, D.S. Weintraub, and M.A. Newell, "The Community Colleges' Role in Developing Students' Civic Outcomes: Results of a National Pilot", Community College Review, 44, 4, 2016, pp. 315-336

[3] L. Wray-Lake, W.M. Rote, T. Gupta, E. Godfrey, and S. Sirin, "Examining correlates of civic engagement among immigrant adolescents in the United States", Research in Human Development, 12, 1-2, 2015, pp. 10-27

[4] B.D. Loader, A.D. Vromen, and M.A. Xenos, "The networked young citizen: social media, political participation and civic engagement", Information, Communication \& Society, 17, 2, 2014, pp. 143-150

[5] L. Wray-Lake, A. Metzger, and A.K. Syvertsen, "Testing multidimensional models of youth civic engagement: Model comparisons, measurement invariance, and age differences", Applied Developmental Science, 21, 4, 2017, pp. 266-284

[6] L. Wray-Lake, A. Metzger, and A.K. Syvertsen, "Testing multidimensional models of youth civic engagement: Model comparisons, measurement invariance, and age differences", Applied Developmental Science, 21, 4, 2017, pp. 266-284

[7] J. Torney-Purta, J. C. Cabrera, K. C. Roohr, O. L. Liu, and J.A. Rios, "Assessing civic competency and engagement in higher education: Research background, frameworks, and directions for next-generation assessment" (Research Report No. RR-15-34), 2015, Princeton, NJ: Educational Testing Service

[8] K.K. Myers and K. Sadagiani, "Millennials in the workplace: A communication perspective on millennials' organizational relationships and performance", $J$ Bus Psychol, 25, 2010, pp. 225-238

[9] K.K. Myers and K. Sadagiani, "Millennials in the workplace: A communication perspective on millennials' organizational relationships and performance", J Bus Psychol, 25, 2010, pp. 225-238
[10] K.K. Myers and K. Sadagiani, "Millennials in the workplace: A communication perspective on millennials' organizational relationships and performance", J Bus Psychol, 25, 2010, pp. 225-238

[11] M.K. Kirlin, "Understanding how organizations affect the civic engagement of adolescent participants", Chapter 2 pp. 19-35 in New Directions for Philanthropic Fundraising, 38, 2002, Winter, Wiley Periodicals Inc.

[12] S. E. Finkel and H. R. Ernst, "Civic Education in Post-Apartheid South Africa: Alternative Paths to the Development of Political Knowledge and Democratic Values", Political Psychology, 26, 3, 2005, pp. 333-364

[13] R. Dassonneville, E. Quintelier, M. Hooghe, and E. Claes, "The Relation Between Civic Education and Political Attitudes and Behavior: A Two-Year Panel Study Among Belgian Late Adolescents", Applied Developmental Science, 16, 3, 2012, pp. 140-150

[14] A. Gillman, "Ideals Without Institutions: Understandings of Democracy and Democratic Participation Among Ecuadorian Youth”, St Comp Int Dev, 53, 2018, pp. 428-448

[15] A. Gillman, "Ideals Without Institutions: Understandings of Democracy and Democratic Participation Among Ecuadorian Youth", St Comp Int Dev, 53, 2018, pp. 428-448

[16] A.K. Cohen and B.W. Chaffee, "The relationship between adolescents' civic knowledge, civic attitude, and civic behavior and their self-reported future likelihood of voting", Education, Citizenship and Social Justice, 8, 1, 2012, pp. 43-57

[17] J. Torney-Purta and J.A. Amadeo, "Niches for Emergent Citizenship in Early Adolescence: An International Perspective", ANNALS, AAPSS, 633, January, 2011, pp. 180-200

[18] J. Torney-Purta and J.A. Amadeo, "Niches for Emergent Citizenship in Early Adolescence: An International Perspective", ANNALS, AAPSS, 633, January, 2011, pp. 180-200

[19] A. Furco, "Higher Education Service-Learning Survey", 1999 retrieved from http://www.servicelearning.org/filemanager/download/HE dSurveyRe1.pdf (Access Date: 10 March 2010)

[20] B. E. Moely and V. Illustre, "The impact of servicelearning course characteristics on university students' learning outcomes", Michigan Journal of Community Service Learning, Fall, 2014, pp. 5-16

[21] K. R. Llewellyn , S. A. Cook, and A. Molina, "Civic learning: moving from the apolitical to the socially just", Journal of Curriculum Studies, 42, 6, 2010, pp. 791-812

[22] F. Reichert, "Who is the engaged citizen? Correlates of secondary school students' concepts of good citizenship", Educational Research and Evaluation-An International Journal on Theory and Practice, 22, 5-6, 2016, pp. 305-332 
[23] M.L. Martinez, P. Cumsille, I. Loyola, and J.C. Castillo, "Patterns of civic and political commitment in early adolescence", Journal of Early Adolescence, 2019, pp. $1-23$ 